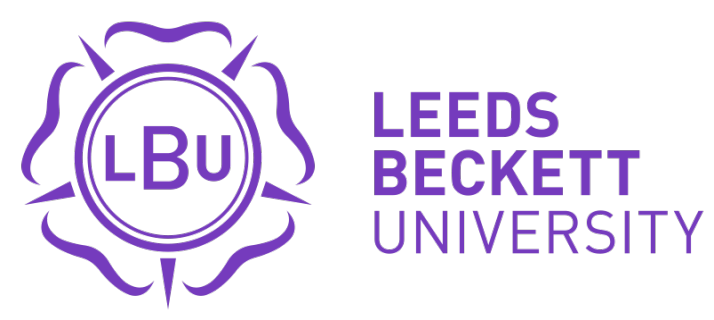

Citation:

Swallow, M and Zulu, SL (2019) Students Awareness and Perception of the Value of BIM and 4D for Site Health and Safety Management. Journal of Engineering, Design and Technology. ISSN 1726-0531 DOI: https://doi.org/10.1108/JEDT-07-2019-0174

Link to Leeds Beckett Repository record:

https://eprints.leedsbeckett.ac.uk/id/eprint/6102/

Document Version:

Article (Accepted Version)

Creative Commons: Attribution-Noncommercial 4.0

The aim of the Leeds Beckett Repository is to provide open access to our research, as required by funder policies and permitted by publishers and copyright law.

The Leeds Beckett repository holds a wide range of publications, each of which has been checked for copyright and the relevant embargo period has been applied by the Research Services team.

We operate on a standard take-down policy. If you are the author or publisher of an output and you would like it removed from the repository, please contact us and we will investigate on a case-by-case basis.

Each thesis in the repository has been cleared where necessary by the author for third party copyright. If you would like a thesis to be removed from the repository or believe there is an issue with copyright, please contact us on openaccess@leedsbeckett.ac.uk and we will investigate on a case-by-case basis. 


\section{Emerald Journal of Engineering,}

\section{Student's Awareness and Perception of the Value of BIM and 4D for Site Health and Safety Management}

\begin{tabular}{|r|l|}
\hline Journal: & Journal of Engineering, Design and Technology \\
\hline Manuscript ID & JEDT-07-2019-0174.R1 \\
\hline Manuscript Type: & Original Article \\
\hline Keywords: & $\begin{array}{l}\text { BIM, 4D Simulation, Health and Safety, BIM Training, Built Environment } \\
\text { Education }\end{array}$ \\
\hline \multicolumn{2}{|l}{} \\
\hline
\end{tabular}




\title{
Student's Awareness and Perception of the Value of BIM and 4D for Site Health and Safety Management
}

\begin{abstract}
Purpose: The education sector is at the forefront of developing tomorrow's construction professionals. It is therefore important that with the current rate of change in the construction industry, education curriculum should be seen to be relevant. An area that is revolutionising the construction industry is the use of Building Information Modelling (BIM), including its potential for improving H\&S on construction sites. This study focuses on the perception of higher education (HE) students on the potential impact of 4D modelling on the management of site health and safety on construction sites.
\end{abstract}

Methodology: Quasi-experimental approach was adopted in order to determine student's perception of the extent to which 4D modelling and simulation can impact H\&S management. Pre-test and post-test students' perceptions of the value of 4D to management of health and safety were compared.

Findings: The influence of education was examined by using two main students groups, one group studying BIM modules within their course while the other group did not. Although minimal perception differences regarding key impacts of $4 \mathrm{D}$ were highlighted, the awareness differences were significant. The study demonstrated the perception of benefits regarding 4D for H\&S being in the planning of site logistics, visualisation, programme accuracy and risk reduction. The study highlights the importance of relevant education, in order to increase awareness of 4D for Health and Safety. 
Implications: While most of the studies reported in academic literature on education and training related to university/tertiary education, this study focused on the higher education level students. It considered this as an equally important cohort as the graduates will also contribute to health and safety management on construction sites. The study also demonstrated the value of including technology-based H\&S training to mirror developments in the construction industry.

Keywords: BIM, 4D Simulation, Health and Safety, BIM Training

\section{INTRODUCTION}

The education sector plays an important role in ensuring that the future workforce has the required skills and knowledge. Construction education is not an exception to this. One of the areas of continued concern for the construction industry has been its relative high health and safety incidences in comparison to many others. The construction industry has one of the highest rates of health and safety incidences. Recent technological developments have shown to provide opportunities for improved construction project management practices, including health and safety management. BIM and its associated applications, has in particular been shown to provide opportunities for enhanced health and safety monitoring on construction projects (Raiz et al., 2017; Wan et al., 2018)

As the industry develops and evolves its processes and technology, it is key that developments in education runs in parallel to allow a cohesion of theoretical understanding and practical experience. The educational structure for future industry professionals has been significantly developed in the UK in recent years concerning both academic and vocational knowledge and skills. This development includes the inclusion of higher apprenticeship routes, using standards 
In light of this incremental uptake and with consideration that students are the decision makers of tomorrow, it would be vital that such processes and technologies are introduced during their studies. This early exposure would allow BIM to become an integral part and an expectation within construction from the beginning of their career and so encourage both a forwardthinking mind-set (Eynon, 2016) and positive safety culture. Their perception and understanding of the processes and technological capabilities is important to the future of the industry. It is not surprising therefore to see different initiatives and approaches to integration of BIM into curriculum. Several studies including, among others, Benner and McArthur (2019), Redondo \& Fonseca Escudero (2018) da Motta Gaspar, et. al. (2019) Abdirad \& Dossick, (2016) and Ghosh et. al. (2015) present examples of this integration.

While a significant number of studies have focused on technology for H\&S in curriculum for university degree qualifications, a few have focused on vocational or diploma level qualifications. Schulte et al (2005) suggests that young people and new workers are particularly susceptible to a high rate of occupational injuries or all groups. They therefore need appropriate H\&S knowledge and skills irrespective of their qualification levels. Berglund et. al. (2019) in their study on occupational accidents in Swedish construction trades found that young adults (age 16-24 years) had the highest number of accidents per 1000 employees while the rate was significantly low numbers among the elderly workers above age 65 years. Similarly, Balanay et al (2017) argued that young adults have a higher injury rate than adults in a similar job. They 
assessed working college students' perception of H\&S issues and concluded that, among other strategies, incorporation of health and safety in curriculum could help improve H\&S performance.

This study contributes to the discourse and focuses on the perceptions of college students undertaking various construction related course, of the effectiveness of 4D modelling as a tool to improve H\&S on construction sites. Recent changes to the curriculum at a college resulted in the introduction of dedicated BIM modules in the first and second year of their studies. This was seen as a platform for students to learn information management processes in line with UK government strategy and industry standards. This development introduced key processes in line with industry standards, methods and procedures and further educate students regarding BIM level 2 and digital technologies including 4D software. The purpose of this study was therefore to evaluate the awareness and perception of students of the extent to which $4 \mathrm{D}$ modelling and simulation would impact on the management of construction site H\&S.

\section{EDUCATION AND TRAINING FOR HEALTH \& SAFETY}

The role of education and training in influencing improved H\&S performance is acknowledged in literature. Goldenhar et al (2001) suggest that H\&S training can be used to reduce the poor H\&S record of the construction industry. Similarly, Mushayi et al (2017) argued that H\&S training is essential to the promotion of positive $\mathrm{H} \& \mathrm{~S}$ culture and climate in organisations, while Bahari (2013) considered safety training as an intervention antecedent to improved safety outcomes in organisations. Many others have demonstrated the role of H\&S training in improving H\&S performance of the construction industry. For example, Dong et al (2004) demonstrated that training is essential to preventing occupational injuries among construction labourers, Namian et al (2016) demonstrated the effect of training on hazard recognition, while 
Bahn et al (2014) examined the impact of training on work-related injuries and found evidence of decreasing trend in work related injuries. Becket et al (2004) also concluded that workers were more willing to attempt to change worksite conditions following training than they were prior to training.

It is therefore important that $\mathrm{H} \& \mathrm{~S}$ be appropriately incorporated in education curriculum. Considering the importance of H\&S training, Gregory et al (2017) suggested that one of the emphasis in $H \& S$ training should be placed on nurturing future $H \& S$ leaders. It can therefore be argued that, students, who are the future leaders of the construction industry (Zulu and Muleya, 2018), should be well informed of health and safety practices. Education curriculum should be seen to be relevant to the advancement of H\&S promotion in the construction industry. Both further and higher education establishments are therefore challenged to include H\&S components in their curriculum. Gambatese (2003) argues that university curriculum for construction related courses should include a focus on construction site safety, as their future involvement will directly or indirectly impact on construction site safety. Pedro et al (2018) argued that education courses should be used to deliver appropriate H\&S skills to students who will one day be decision makers regarding $H \& S$ in construction. It is essential that students are equipped with the necessary H\&S skills to take with them into industry. The importance of H\&S skills is also suggested by Ahmed et al (2014) who examined key skills required by construction management graduates. They identified H\&S as one of the top five most important skills desired in a new employee in construction management. A number of studies have therefore examined the integration of H\&S in education curriculum. For example, Misnan et al (2017) examined the integration of safety and health in engineering programmes curriculum in Malaysia. 
The need for graduates to have appropriate skills for industry practice is also acknowledged in literature. Zakaria (2017) posited that the education institutions are placed in a position to produce graduates with relevant skills for their host societies. There is then an expectation that education institutions will produce graduates who have the requisite skills. This is particularly important considering the evidence that having appropriate skills set has a positive impact on safety culture and performance (Zou et al (2013). This then places a need for academic curriculum to continuously improve to meet current workplace demands (Ahmed, 2014).

Digital technologies are changing the landscape of the construction industry including safety management. It is essential that students graduate with the necessary digital skills necessary for management of the construction process including construction site safety management. Studies have examined at various digital technologies for health and safety training and management. For example, a number of studies have focused on the use of 3D gaming environments for construction safety education (Lin et al, 2011). Pedro and Park (2014) argued for a change in delivering $H \& S$ education at university level and suggested that VR based activities provide a suitable platform for students to have a 'virtual' hands-on learning of H\&S matters.

\section{BIM AND HEALTH \& SAFETY}

Advances in BIM have provided a challenge for the construction industry to innovate. The BIM mandate, set in the government construction strategy 2011 required that centrally procured government projects should operate at BIM level 2 by the year 2016 (Cabinet Office, 2011, p.14). The government strategy provided impetus for the adoption of BIM in the UK construction industry. It is therefore not surprising to see, in literature, a focus on BIM and education as there is need to train graduates who have the requisite skills. For example Zhang 
et al (2018) explored the use of team based learning to enhance BIM competence among civil engineering and management students. Kolaric et al (2017) examined educational approaches to BIM in construction management courses in Croatia, while, Acikgoz (2018) argued for the need for curriculum to catch up with advances in BIM in Turkey. Xu et al (2018) points out that, with advances in BIM technology, the traditional approaches to teaching does not reflect the requirements of modern professionals. It is therefore important that education curriculum should be re-focused to produce graduates who are BIM ready. One of the advantages of BIM is that it provides a platform for simulation of projects and therefore enhancing the understanding of the project by its stakeholders.

BIM provides a platform for structured information creation and management, which could be key to reducing both project risk and wasteful processes, particularly on site where capital costs of the project can be affected by poor information (Pittard \& Sell, 2016). These processes are defined within a suite of British Standard Institute (BSI) documents in order for the industry to understand and implement BIM level 2 in the UK. The PAS1192-6:2018 standard focuses on collaborative sharing and use of structured health and safety information, thus linking BIM processes to safety management. PAS1192-6:2018 states that "Each participant shall adopt the use of $3 \mathrm{D}$ or $4 \mathrm{D}$ construction sequencing model(s) to the support the development and visualisation of safe methods of access and working" (BSI, 2018, p11). This inclusion within the BIM level 2 framework brings the use of 4D under the spotlight as a tool within the process to reduce safety risk.

4D modelling requires synchronizing the information model components with schedule information, creating visual construction sequencing (Hardin \& Mccool, 2015). The concept and application of 4D allows the schedule information to be visualised, project team members 
are able to assess logic and sequence of the proposed plan and ascertain if this is possible or most effective. This can allow opportunities for alternative options to be explored (Carvajal, 2005) and to rehearse project activities prior to commencement in order to show how the plan would play in a 'virtual world'. While BIM and 4D modelling promises added benefits to the management of health and safety in construction, Chavin (2018) suggests that due to client demands, the adoption of BIM level 2 has not grown as would be expected despite the industries ambition to move to BIM level 2 (Waterhouse, 2018).

The use of 4D modelling and simulation should be a motivating feature for construction education providers. Gledson and Dawson (2017) demonstrated how the use of simulation through BIM-enabled virtual reality projects resulted in students enhanced subject-matter understanding that would not have been the case if traditional teaching methods where used. Similarly, Hu (2018) demonstrated how BIM enabled pedagogy (BEP) has a more effective approach than traditional teaching methods. The quest for BIM-enabled education has led to many scholars investigating approaches to integration of BIM in education (Sampaio, 2018; Garyaeva, 2018; Huang, 2018; Ferandiz, 2018).

4D simulation is seen as a useful tool for improving the understanding of H\&S issues. Similar to studies that have demonstrated the effectiveness of gaming in H\&S education, it is argued that $4 \mathrm{D}$ simulation can be an effective classroom tool for education in general and H\&S. For example, Xie et al (2018) demonstrated how modelling and simulation on CAD platform could be used to teach concepts and inform design decisions. Toole (2005) identified four sets of barriers to improved H\&S performance, among which was lack of understanding of construction processes. It is important therefore, that tools that can help students and professionals have a better understand of the construction process should be employed. Maraqa 
(2016) acknowledges that there are two aspects to H\&S on construction projects- construction site safety and design for safety. It is necessary that students should not just be made aware of the importance of the design related safety practices, but also factors that can contribute to site safety management on the construction site. Dawood et al (2015) demonstrated how the use of interactive games and 4D concepts could improve users' engagement and their ability to identify H\&S hazards. Gao et al (2018) conducted a systematic review of literature and performed a gap analysis to compare the effectiveness of training techniques between traditional approaches and computer aided approaches. They concluded that there is evidence that computer aided methods where more effective in delivering the technical content of training.

\section{D MODELLING AND CONSTRUCTION HEALTH AND SAFETY MANAGEMENT}

The current literature regarding the use of digital software and the processes for building information modelling in the construction industry has increased over recent years. Guo et al., (2016) however suggests that there is an absence in literature for the critical review of technology, particularly visualization technology and the impact on health and safety management.

Key benefits of BIM are acknowledged in various literature, including clear visualisation of the project and sequencing (Mordue \& Finch, 2014), project time reduction (Hardin \& Mccool, 2015), improved communication (Sulankivi, 2010), logistic planning (Sulankivi, 2010; Mordue \& Finch, 2014). Increased health and safety management (Saeedfar (2017), schedule progress and monitoring (Mordue \& Finch, 2014), accuracy of scheduling and logic (Mordue \& Finch, 2014) and waste reduction (Geldard, 2017; Barnes \& Davis, 2014) are also key benefits. 
Working within BIM level 2, the importance of a collaborative working environment for accurate 4D scheduling in a virtual space is essential. Azhar et al., (2012) suggested that that the development of a digital, virtually simulated environment, created by a collaborated team with virtual technology is to be a "revolutionary development" within the field of construction. With further emphasis of the importance of such a vital tool, Barnes \& Davis (2014) argue that $4 \mathrm{D}$ enables an improvement in the planning and management of the construction phase. Research by Kassem et al., (2012) also supports this and suggests that 4D is becoming a key driver for change in the construction industry although there are barriers in its adoption.

In the field of construction project management, Mordue \& Finch (2014) suggests that creating this synergy between BIM and health and safety has been seen as a movement forward. They note that there is value in its adoption and that BIM has been recognised and acknowledged by the Heath and Safety Executive (HSE). Mordue \& Finch (2014) also refer to the term "virtual design and construction" (VDC) as the use of enriched models as a resource to increase the accuracy of planning during the design and construction process. Their research is on BIM and health and safety management highlighted the use of 4D as an essential tool, specifically in the planning of health and safety during the pre-construction process. They also identified the incorporation of virtual reality within the 4D simulation involving further use of digital technology and providing a fully immersed environment for precise site planning. This method allows further interaction to identify hazards at any stage of the scheduled construction process, using this technology to enable more informed decisions to be made in design and preconstruction phases. The use of virtual reality for this purpose was also emphasised in the work of Hardin \& Mccool (2015), stating that project simulation through a virtual environment is becoming a key method in understanding the projects concepts including site safety procedures. 
Cousins (2016) also agrees and suggests that the use of 4D planning and simulation to rehearse activities at any point of the proposed build could be a key tool to allow accurate planning of safety. Cousins (2016) states:

\begin{abstract}
4D BIM enables us to digitally rehearse the installation and identify any hazard, or potential hazard, and try to mitigate it during pre-construction. There are a myriad of examples where logistics, access requirements, scaffolding etc. are fully integrated into one BIM construction model, which makes spotting hazards a lot easier compared to traditional $2 D$ methods.
\end{abstract}

The literature highlights the use of 4D modelling for health and safety management in design and pre-construction, however, the extent of the practical applications of the software at during the construction stages and how education could influence this adoption is not identified.

Zhou et al., (2012) highlights the importance and interconnectivity between digitally designed processes and health and safety management to promote collaboration within the project in a 'mindful manner'. In order to address safety concerns the study addresses various forms of technology and their applications in the industry, although suggesting that there are "various digital tools for addressing safety issues in the construction phase, but few tools to support design for construction safety". A number of key benefits of 4D modelling in regards to for health and safety management. As the BSI (2018, pV) state in PAS1192-6:2018 a 4D animation can be used to review, assess and communicate construction options, hazards and risk. A 4D animation of difficult construction sequences is more easily understood by those who have to take responsibility and accountability of risk mitigation, control and management. The use of 3D and 4D models in design supports the principles relating to an 'inherently safer design', 'safety by design and the legislative duties on designers 
According to Sulankivi (2010) the use for 4D should be a central focus in the management of site health and safety. For example, 4D BIM supporting software can be used to display site layout plans, which can be co-ordinated for health and safety risk analysis. The research, grounded by 'BIM safety' also highlighted the potential for challenges and limitations, demonstrating that the use of this process and technology can be used for communication between the project team including site level and to allow for accurate visualisation of site safety arrangements and control measures. Saeedfar (2017) discusses the further use of health and safety data within the model allowing, "Live safety tracking". The live data within the model for tracking objects, processes and operatives. The levels of dust and noise as well as high-congested areas can be captured and used as a method of monitoring using sensors and tag systems.

\section{BIM AND 4D WITHIN THE CURRICULUM}

Shelbourn et al,. (2017) studied the students perception of the intergration of BIM into the undergraduate curriculum in the USA and UK, the study highlighted a debate as to if BIM should be a standalone unit or intergrated into the courses. The reasarch higlighted considerations in order for BIM to become inclusive within the HE curriculum including technical skills, teamworks and collaborative working. The study suggested that BIM provides an opportunity to further engage students and for students to have a deeper understanding into the construction methodology of buildings. Gordan et al., (2009) suggested that the incorporation of BIM within the educational curriculum was essential, as these processes are quickly becoming the industry norm. Understanding these collaborative processes and technology was not only key to improve communication skills and technical knowledge but also increased the student's employability. These employability factors are due to industry 
contractors beginning to adopt specialist processes such as 4D and 5D modelling. A view also shared by Adbirad \& Dossick (2016) who proposes that BIM within university curriculum is essential due to industry demands and that the development of strategies for delivering BIM is complex.

Research by Clevenger et al. (2010), identified that there are a number of methods in which BIM can be incopriated into the curriculum, these include stand alone coures, updating exisiting coures to inbed BIM or both. Ghosh et al., (2013) highlighted that implimenting BIM within the curriculum is to be challenging due to time and student's knowledge retention. It was suggeted that delievering BIM as a standalone course can provide students with essential knowledge and skills although without further intergration into other courses or areas of the curriculum, students found it differcult to retain these skills.

It can therefore be argued that the incorporation of BIM into the curriculum is essential to meet industry needs and to increase overall knowledge of the construction process. The inclusion of BIM as standalone units as well as imbedding within whole courses is suggested in order to retain these skills and knowledge. Considering that BIM and 4D are seen to be enhance health and safety management, it is essential that students, who are the decision makers of tomorrow, should be made aware of this opportunity to improve health and safety performance in the construction industry. It is against this background that this research was conducted.

\section{THE RESEARCH METHODOLOGY AND APPROACH}

The quasi-experimental design involving a pre-test and post-test analysis of student perceptions was adopted for this research. The pre-test and post-test approach has been widely used in education research involving students including Rose et al., (2000), Bas, (2011) and van 
Velthuijsen (2018). Quantitative data was collected from HE students studying level 4/5 qualifications in construction, civil engineering and building services in the form of questionnaires and a quasi-experiment. This study was carried out in order to evaluate the awareness, perceived benefits and value of 4D from the viewpoint of students working in industry. As these students are to become future decision makers, their perception of this process and technology is a key factor.

The study involved the use of two groups who studied levels $4 \& 5$ at the same institution, due to the phase out of the 2010 course specification, both the 2010 and 2017 specification where delivered concurrently. Both groups studied on a part time basis and worked in the construction and infrastructure sector within various professional roles. A sample group of 82 part time HE students referred to as the 'BIM groups' studied the level 4/5 course under the 2017 higher national course specification including a level 4 BIM unit. The unit exposed these students to key terms and benefits including 4D and processes within the PAS1192 suite of documents involving specifics of PAS1 192-6:2018. The second group were a control group of 26 part time HE students, which are referred to as 'non-BIM groups'. This control group studied the 2010 higher national specification with identical attendance pattern to the 'BIM groups' but were unable to undertake the BIM unit as the course was running using the older higher national course specification. Due to not undertaking this unit the 'non-BIM groups' would not have been explicitly exposed to these terms, documents, technology and processes during their course. The questionnaires were designed to assess the student's awareness, adoption and perception of BIM and 4D. A quasi-experiment was carried out to document if exposure to the process and application of 4D would alter their perception of its impact on safety. The perception of the students is an important factor, as their perception may influence the decisions to adopt $4 \mathrm{D}$ in the current, next and future generations. 
In quasi-experiments, participants are not randomly assigned (Bryman and Bell, 2007), but identified based on suitability for the research. The use of a control group was implemented in order to compare the results and identify any major bias, highlighting if further knowledge and formal training have an effect on this awareness and perception. The quasi-experiment approach (Bryman \& Bell, 2007) focused on evaluating the students perception of 4D by gathering quantitative data using a pre-test and post-test design. This method was used to study participants perception before and after an intervention (Kowalczyk, 2018), and document any statistical difference. This design required both groups to answer a pre-test questionnaire to determine their awareness and initial perception of BIM and 4D and its impact on safety. The intervention was in the form of a demonstration, involving a discussion of a high profile case study including a visual simulation of the construction methodology, allowing participants to overview the software whilst understanding the key processes. An identical demonstration was shown to both groups within the classroom environment. The post-test questionnaire required the participants to assess the process and software in a number of key areas including specific health and safety planning factors. The data from the control group in the quasi-experiment could then be used to identify any major differences between the 'BIM groups' and 'non-BIM groups' and assess if the demonstration altered their perception and if specific subject education effected the awareness or perception.

\section{ANALYSIS AND DATA FINDINGS}

\section{The sample}

The primary objective of the study was to collect data to study the impact of education regarding the awareness and perception of BIM and 4D concerning health and safety management. Considering the nature of the experiment and ease of access to participants a high 
response rate of $96 \%$ was achieved. This percentage could have been influenced by the personal conducting of the survey as Nulty $(2008$, p303) states “... face-to-face administration results in higher response rates".

Table 1 shows the courses of the students in the two groups, while table 2 and table 3 shows the mode of study and their job roles respectively. It is noted in table 2 that $100 \%$ of the students in both groups where part time and $99 \%$ working in influential positions in the construction industry.

Table 1: Course studied at level 4/5

Table 2: Mode of study

Table 3: Participants' roles within industry

The data shows a high percentage of participants in the 'BIM groups' studying building services engineering (41\%) and construction (32\%) with lower participants from civil engineering and quantity surveying courses. The results were mainly due to the specific units the disciplines study (as the BIM unit was not part of the 'non-BIM' group's course) and influenced by practical access to participants. The 'non-BIM groups' shows a contrast to this, with $0 \%$ of students within this control group being enrolled on building services engineering and QS courses and the group made up of construction and civil engineering students, this is due to their level 4/5 course specification not including the BIM as an available unit.

Both course specifications allow the students to study on either a part time of full time bases, the data in table 2 shows that $100 \%$ of the 'BIM groups' and $100 \%$ of the 'non-BIM groups' 
where studying part time, meaning they also in employment within industry. The only data used are from part time students in order to reduce variables in this study.

\author{
Table 4: Awareness of BIM
}

Table 5: Adoption of BIM level 2

\title{
Awareness of BIM and adoption in their organisation
}

Participants were asked to identify their awareness of BIM, as table 4 shows, students within the 'BIM groups' recorded a 100\% 'yes' response with the 'non-BIM groups' having an $85 \%$ response. The students were also asked to state their company's current adoption of BIM level 2, table 5 indicates the 'BIM groups' and 'non-BIM groups' responses in regards this adoption. The data shows that BIM adoption of less than $50 \%$ of projects for both the 'BIM groups' and 'non-BIM groups' ranked top. The awareness and understanding of BIM and level 2 adoption is important to this study, the data indicates that education could have an impact on this awareness. The awareness of BIM could also have impact of the understanding of PAS1192 standards and the use of BIM software including those with 4D capabilities.

\section{Table 6: Awareness of 4D modelling}

Table 7: Company use of 4D modelling

\section{Awareness and adoption of 4D modelling}

In order to document current adoption and use of 4D modelling, the participants were first asked if they were aware of such processes and technology. Table 6 shows the responses to this 
awareness. The 'BIM groups' who had received formal education in BIM responded with a high 'yes' at $87 \%$, this may have been influenced by their recent formal exposure to such terminology, technology and processes. The data shows when same question was asked to the 'non-BIM groups', the 'yes' response in this group was significantly lower at $38 \%$.

Further to the awareness, data was gathered on the extent to which the organisations in which the students worked used 4D modelling. Table 7 shows, a minority of $34 \%$ of the 'BIM groups' participants were employed by companies using 4D software. The data indicates an even lower response of $15 \%$ given by those within the 'non-BIM groups' suggesting a low adoption within both sample groups.

\section{A Pre-test and post-test of perception of 4D}

The initial stage involved students answering designed questions regarding their perception of the impact of 4D on managing various aspects including costs, scheduling and health and safety. Table 8 identifies these benefits and shows the students responses. Once this initial perception was assessed, a demonstration of 4D capabilities was presented to the both student groups.

\section{Table 8: Benefits of 4D modelling}

The rakings indicate a clear pattern from both groups, the visual benefits of the process being ranked as the highest and reduction of waste as the lowest benefit of 4D. Health and safety was however raked differently in both groups although positioned in the middle - bottom ranking in both data sets. Other high scoring benefits been the accuracy of scheduling and communication, which link to key literature (Mordue \& Finch, 2014). The data indicates a low 
response in the reduction of waste and agreeing workflows. The data also indicates that industry perception of the benefits is overall lower in all but one factor (communication).

\section{Impact on Health and Safety}

The data shown in table 9 provides an overview of the initial perception of 4D used to reduce health and safety risk and the perception of after the 4D software demonstration (pre-test and post-test scores). The results from both groups indicate that there is a minor reduction in perception after the demonstration in both groups. This minor reduction would suggest that the intervention had minimal effect on the student's perception of 4D in regards to its impact on health and safety.

Table 9: Pre and post test results (perception of $4 D$ as a tool for health and safety management)

When assessing the demonstration in specific regards to health and safety, the participants were asked to rate the extent to which they agreed the software would increase the planning of site safety. This data would be useful in assessing the capability of 4D in planning for specific site hazards, which would assist in its effective control.

Table 10 identifies key planning areas, the data indicates a clear pattern and that site logistics and plant movement where rated highest within the two groups. These areas where the areas of most concerns within the industry feedback, questionaries' and HSE current statistics showing promise for the use of this software and process for these means. The data also shows that all three groups rated planning for manual handle tasks the lowest, indicating that this process would be less effective in this planning task. 
Table 10: Impact on planning for health \& safety

The findings presented above provides useful context of students perceptions of the value of 4D for site health and safety management. The data seems to suggest that while there were initial differences in the awareness of 4D from those studying BIM and those who are not, having further exposure to the software had no positive impact on students perception of its benefits for safety management. There is however, agreement among students of the potential benefits of 4D for health and safety in particular regards to its visualisation and planning of plant movement and site logistics.

\section{CONCLUSION}

The purpose of this paper was to examine students' awareness and perception of the impact of 4D modelling and simulation on management of construction site health and safety. The importance of health and safety is widely acknowledged in practice and theory, therefore it is of paramount importance that the next generation of construction industry decision makers are aware of the innovative ways in which site health and safety can be managed. Due to the rapid increase of information management processes this link between BIM and health and safety is becoming defined within industry standards and practice. The data from this study showed the importance of education and training as a marked difference in awareness of BIM and 4D between the two groups was evident. Students who had studied BIM units demonstrated a higher awareness of both BIM and 4D than those in the control 'non-BIM' groups. The data indicated a low adoption in the industry from the participants surveyed, further supporting the suggestion that awareness of $4 \mathrm{D}$ is influenced by educational studies. 
The key impacts of 4D were identified including: visual, programme accuracy and project risk reduction benefits. These factors were consistent amongst students perceptions. While the above points to the general perceptions, the data collected from in this study shows student perception before and after exposure of 4D software in specific regards to safety. The quasiexperiment identified minimal change before and after the intervention and unexpectedly showed a reduction in their perception. This said, the data shows the 'BIM groups' perception of $4 \mathrm{D}$ reducing safety risk being 3.21, while the 'non-BIM groups' was 3.62 from a possible 5 indicating an overall positive response to its benefits for safety management.

By analysing the data from this study shows the students perception of the key benefits of 4D for health and safety being in the planning of site logistics and planning of site plant, each ranking within the top two factors in both groups. Further, increased visualisation the project and effective communication, have been highlighted as key advantages of $4 \mathrm{D}$ in this study. The study indicates a positive perception of 4D from these future decision makers. The study also suggests that education has an impact in the awareness of $4 \mathrm{D}$, as demonstrated by the differences between the two groups in the study.

Based on the findings summarised above, it can be the study concludes that education and training can be a significant factor in influencing students' perceptions of awareness of both general BIM benefits and usefulness of 4D simulation to the overall management of health and safety on construction sites. The study highlights the importance of the inclusion of BIM within the education of professionals in the industry. If the industry is aiming to work in accordance with PAS1192-6:2018 in incorporating 4D for safety within projects as the norm, the educational curriculum must endeavour to keep up to date with industry progression in terms of standards and practice. This is essential to ensure that students are equipped with the 
knowledge of these advancements in both process and technology in order to make effective judgements on this adoption.

\section{Limitation and future work}

The study was based on sample from two groups, the 'BIM group' and the 'None BIM group'. The sample size for the None BIM group was relatively small in comparison to the 'BIM group' and therefore some of the statistical analysis could not be used. The data however provided a useful basis for the comparison of the perceptions between the two groups. Furthermore, the study was based on a cross sectional approach representing one cohort of students. Future work would be useful, that would take a longitudinal approach to provide a comparison of the perceptions of students in different cohorts. This would also enable collection of data from a large sample size to enable use of further incisive inferential statistical research.

\section{REFERENCES}

Abdirad, H. \& Dossick, C. (2016) BIM Curriculum Design in Architecture, Engineering and Construction Education: a Systematic Review, Journal of Information Technology in Construction, 21 pp. $250-271$

Abdirad, H., \& Dossick, C. S. (2016). BIM curriculum design in architecture, engineering, and construction education: a systematic review. Journal of Information Technology in Construction (ITcon), 21(17), 250-271.

Açıköz, E. K. (2018). Catching Up With BIM: A Curriculum Re-Design Strategy. International Journal of Contemporary Urban Affairs, 2(3), 40-48.

Ahmed, S. M., Yaris, C., Farooqui, R. U., \& Saqib, M. (2014). Key attributes and skills for curriculum improvement for undergraduate construction management 
programs. International Journal of Construction Education and Research, 10(4), 240254.

Azhar, S. Khalfan, M. \& Maqsood, T (2012) Building information modelling (BIM): now and beyond. Australasian Journal of Construction Economics and Building

Bahari, S. F. (2013). An investigation of safety training and safety outcome in a manufacturing plant. Sains Humanika, 64(1).

Bahn, S., \& Barratt-Pugh, L. (2014). Safety training evaluation: The case of construction induction training and the impact on work-related injuries in the Western Australian construction sector. International Journal of Training Research, 12(2), 148-157.

Balanay, J. A. G., Adesina, A., Kearney, G. D., \& Richards, S. L. (2014). Assessment of occupational health and safety hazard exposures among working college students. American journal of industrial medicine, 57(1), 114-124.

Baş, G. (2011). Investigating the effects of project-based learning on students' academic achievement and attitudes towards English lesson. The online journal of New Horizons in Education, 1(4).

Becker, P., \& Morawetz, J. (2004). Impacts of health and safety education: Comparison of worker activities before and after training. American journal of industrial medicine, 46(1), 63-70.

Benner, J., \& McArthur, J. J. (2019). Lessons Learned from a Multi-year Initiative to Integrate Data-Driven Design Using BIM into Undergraduate Architectural Education. In Advances in Informatics and Computing in Civil and Construction Engineering (pp. 857-864). Springer, Cham.

Berglund, L., Johansson, M., Nygren, M., Samuelson, B., Stenberg, M., \& Johansson, J. (2019). Occupational accidents in Swedish construction trades. International Journal of Occupational Safety and Ergonomics, 1-10. 
Bryman, A. \& Bell, E. (2007) Business Research Methods. $3^{\text {rd }}$ Ed. New York: Oxford

Bsi British Standards Institution. (2018) PAS1192-6:2018 specification for the collaborative sharing and use of structured Health and Safety information using BIM. London: Bsi Standards limited

Cabinet Office. (2013) Construction 2025. Cabinet office: London Cabinet office

Carvajal, A. (2005) The use of visualisation technologies for the integration of building enduser perspectives, a managerial approach. Proceedings of American society of civil engineers conference Vol 179

Chevin, D. (2018) BIM Level 2 uptake slow but AR and Automation up. Construction Manager. April pp. 22-24

da Motta Gaspar, J. A., Ruschel, R. C., \& Monteiro, E. Z. (2019). Integrated and Collaborative Architectural Design: 10 Years of Experience Teaching BIM. In Advances in Informatics and Computing in Civil and Construction Engineering (pp. 865-872). Springer, Cham.

Dawood, N., Miller, G., Patacas, J., \& Kassem, M. (2014). Construction health and safety training: the utilisation of 4D enabled serious games. Journal of Information Technology in Construction.

Dawood, N., Miller, J., \& Yabuki, N. (2012, September). Incorporating H\&S into design and construction: the case for integrating serious games engines technologies and 4D planning for collaborative work. In International Conference on Cooperative Design, Visualization and Engineering (pp. 255-263). Springer, Berlin, Heidelberg.

Dong, X., Entzel, P., Men, Y., Chowdhury, R., \& Schneider, S. (2004). Effects of safety and health training on work-related injury among construction laborers. Journal of occupational and environmental medicine, 46(12), 1222-1228.

Eynon, J. (2016) Construction Managers BIM Handbook. Oxford: Wiley Blackwell 
Ferrandiz, J., Banawi, A., \& Peña, E. (2018). Evaluating the benefits of introducing "BIM" based on Revit in construction courses, without changing the course schedule. Universal Access in the Information Society, 17(3), 491-501.

Gambatese, J. A. (2003). Safety emphasis in university engineering and construction programs. Construction safety education and training - A global perspective.

Gao, Y., Gonzalez, V., \& Yiu, T. W. (2018). The Effectiveness of Traditional Tools and Computer-Aided Technologies for Health and Safety Training in the Construction Sector: A Systematic Review. arXiv preprint arXiv:1808.02021.

Garyaeva, V. (2018). Formation of competitive skills of civil engineers in the field of BIM technologies. In MATEC Web of Conferences (Vol. 170, p. 01077). EDP Sciences.

Ghosh, A. Parrish, K. \& Chasey, A. (2013) Implementing a Vertically Integrated BIM Curriculum in an Undergraduate Construction Management Program. International Journal of Construction Educational and Research, 11 (2) pp 121-139

Ghosh, A., Parrish, K., \& Chasey, A. D. (2015). Implementing a vertically integrated BIM curriculum in an undergraduate construction management program. International Journal of Construction Education and Research, 11(2), 121-139.

Gledson, B. J., \& Dawson, S. (2017). Use of simulation through BIM-enabled Virtual Projects to enhance learning and soft employability skills in Architectural Technology education. In Building Information Modelling, Building Performance, Design and Smart Construction (pp. 79-92). Springer, Cham.

Goldenhar, L. M., Moran, S. K., \& Colligan, M. (2001). Health and safety training in a sample of open-shop construction companies. Journal of safety Research, 32(2), 237-252.

Gordon, C. Azambuja, A. \& Werner, A. (2009) BIM across the construction curriculum. In: El-Gafy, M. proceeding of the 2009 ASC Region III Conference October 21-24, 2009, Dowers Grove Illinois. pp 19-21 
Gregory, P., Pacurar, C., \& Wetter, M. (2017, January). Safety, Health and Environmental (SH\&E (Training) that Builds Safety Culture. In ASSE Professional Development Conference and Exposition. American Society of Safety Engineers.

Guo, H. Yu, Y. \& Skimore, M. (2016) Visualization technology-based construction safety management in Automated construction. Elsevier

Hardin, B. \& Mccool, D. (2015) BIM and Construction Management Proven Tools, Methods and Workflows. $2^{\text {nd }}$ Edition. Indiana: Wiley

Health and Safety Executive. (2015) Managing Health and Safety in Construction, Construction (Design and Management) Regulations 2015. HSE

Hu, M. (2018). BIM-Enabled Pedagogy Approach: Using BIM as an Instructional Tool in Technology Courses. Journal of Professional Issues in Engineering Education and Practice, 145(1), 05018017.

Hu, Z. Zhang, J. \& Deng, Z. (2008) Construction Process Simulation and Safety Analysis Based on Building Information Modelling and 4D Technology, Tsinghu Science and Technology. Science direct, EBSCOhost

Huang, Y. (2018). Developing a Three-level Framework for Building Information Modeling Education in Construction Management.

Kassem, M. Brogden T. \& Dawood, N (2012) BIM and 4D planning a holistic study of the barriers and drivers to widespread adoption. Journal of Construction Engineering and Project Management, 5 pp 1- 10

Kolarić, S., Vukomanović, M., Stober, D., \& Dolaček-Alduk, Z. (2017). Assessing educational approaches to building information modelling (BIM) at construction management master studies in croatia. Technical Gazette, 24(4), 1255-1262. 
Kowalczyk, D. (2018) Pre-test and post-test design: definition and example. [online] Available from http://wwwstudy.com/academy/lessonpretest-posttest-desgndeffinition-example [accessed 17 April 2018]

Maraqa, M. A., Sweedan, A. M., \& Zaneldin, E. (2016). Inclusion of Construction Health and Safety in Engineering Programs in the MENA Region: Assessment and Potential Enhancement. In Advances in Engineering Education in the Middle East and North Africa (pp. 261-299). Springer, Cham.

Misnan, M. S., Azmi, W. F. W., Mohamed, S. F., Ramly, Z. M., Yusof, Z. M., \& Othman, N. (2017). Integration of design safety into curricula in the undergraduate programs: the academician perspective. Open journal of safety science and technology, 7(03), 106.

Mordue, S. \& Finch, R. (2014) BIM for Construction health and Safety. Newcastle: RIBA

Mushayi, T., Deacon, C., \& Smallwood, J. (2017, September). The Effectiveness of Health and Safety Training and Its Impact on Construction Workers' Attitudes, and Perceptions. In International Conference on Engineering, Project, and Product Management (pp. 235-244). Springer, Cham.

Namian, M., Albert, A., Zuluaga, C. M., \& Behm, M. (2016). Role of safety training: Impact on hazard recognition and safety risk perception. Journal of Construction Engineering and Management, 142(12), 04016073.

Pedro, A., \& Park, C. S. (2014). A Construction Safety Education System Based On Interactive Virtual Reality. Achieving Sustainable Construction Health and Safety.

Pedro, A., Chien, P. H., \& Park, C. S. (2018, April). Towards a Competency-based Vision for Construction Safety Education. In IOP Conference Series: Earth and Environmental Science(Vol. 143, No. 1, p. 012051). IOP Publishing.

Redondo, E., \& Fonseca Escudero, D. (2018). BIM implementation in the AEC curriculum. A quasi-experimental case study of the architectural engineering (AE) bachelor's degree 
at the United Arab Emirates university (uaeu) (Doctoral dissertation, Universitat Politècnica de Catalunya (UPC)).

Riaz, Z., Pärn, E. A., Edwards, D. J., Arslan, M., Shen, C. and Peña-Mora, F. (2017) BIM and sensor-based data management system for construction safety monitoring. Journal of Engineering Design and Technology, 15(6), pp. 738-753. DOI: 10.1108/JEDT-032017-0017

Rose, F. D., Attree, E. A., Brooks, B. M., Parslow, D. M., \& Penn, P. R. (2000). Training in virtual environments: transfer to real world tasks and equivalence to real task training. Ergonomics, 43(4), 494-511.

Saeedfar, A. (2017). Blog: Role of Safety in BIM. [Online] Assemble Systems. Available from: https://assemblesystems.com/blog/role-of-safety-in-bim/ [Accessed 25 February. 2018].

Sampaio, A. Z. (2018, July). Introduction of BIM methodology in education: Concept and application. In 4th International Conference on Higher Education Advances (HEAD'18) (pp. 19-27). Editorial Universitat Politècnica de València.

Schulte, P. A., Stephenson, C. M., Okun, A. H., Palassis, J., \& Biddle, E. (2005). Integrating occupational safety and health information into vocational and technical education and other workforce preparation programs. American Journal of Public Health, 95(3), 404411

Shelbourn, M. Macdonald, J. McCuen, T. \& Lee, S. (2017) 'Students' perceptions of BIM education in the higher education sector : a UK and US perspective'. Industry \& Higher Education, 31 (5) pp. 293-304

Sulankivi, K. (2010) 4D-BIM for Construction Safety Planning. VTT Technical Research Center of Finland 
Swallow, M. R., \& Zulu, S. (2018). Benefits and Barriers to the Adoption of 4D Modelling for Site Health and Safety Management. Frontiers in Built Environment, 4, 86. https://doi.org/10.3389/fbuil.2018.00086

Toole, T. M. (2005). Increasing engineers' role in construction safety: Opportunities and barriers. Journal of Professional Issues in Engineering Education and Practice, 131(3), 199-207.

van Velthuijsen, E. L., Zwakhalen, S. M., Warnier, R. M., Ambergen, T., Mulder, W. J., Verhey, F. R., \& Kempen, G. I. (2018). Can education improve clinical practice concerning delirium in older hospitalised patients? Results of a pre-test post-test study on an educational intervention for nursing staff. BMC medical education, 18(1), 59.

Wan, A., Zulu, S. and Khosrowshahi, F (2018) Potential of using BIM for improving Hong Kong's Construction Industry, in International Journal of 3-D Information Modelling (IJ3DIM); DOI: 10.4018/IJ3DIM.2018070104

Xu, J., Li, B. K., \& Luo, S. M. (2018). Practice and Exploration on Teaching Reform of Engineering Project Management Course in Universities Based on BIM Simulation Technology. EURASIA Journal of Mathematics, Science and Technology Education, 14(5), 1827-1835.

Zakaria, S. (2017). The Ever Challenging Environment of Producing Knowledgeable and Skillful Graduates: Changing the Culture of Higher Education of Institutions in Teaching and Learning Approaches. Universal Journal of Educational Research, 5(5), 705-709.

Zhang, J., Wu, W., \& Li, H. (2018). Enhancing building information modeling competency among civil engineering and management students with team-based learning. Journal of Professional Issues in Engineering Education and Practice, 144(2), 05018001. 
Zhou, W. Whyte, J. \& Sacks, R. (2012) Constriction Safety and digital Design: A Review. Automation In Construction, 22, Planning Future Cities-selected papers from the 2010 eCAACe Conference, ScienceDirect EBSCOhost.

Zou, P. X., \& Sunindijo, R. Y. (2013). Skills for managing safety risk, implementing safety task, and developing positive safety climate in construction project. Automation in Construction, 34, 92-100.

Zulu, S and Muleya, F (2018) A student perspective of ethics in the Zambian construction industry. Journal of Engineering, Design and Technology, https://doi.org/10.1108/JEDT-04-2018-0074. 
Page 31 of 40

Journal of Engineering, Design and Technology

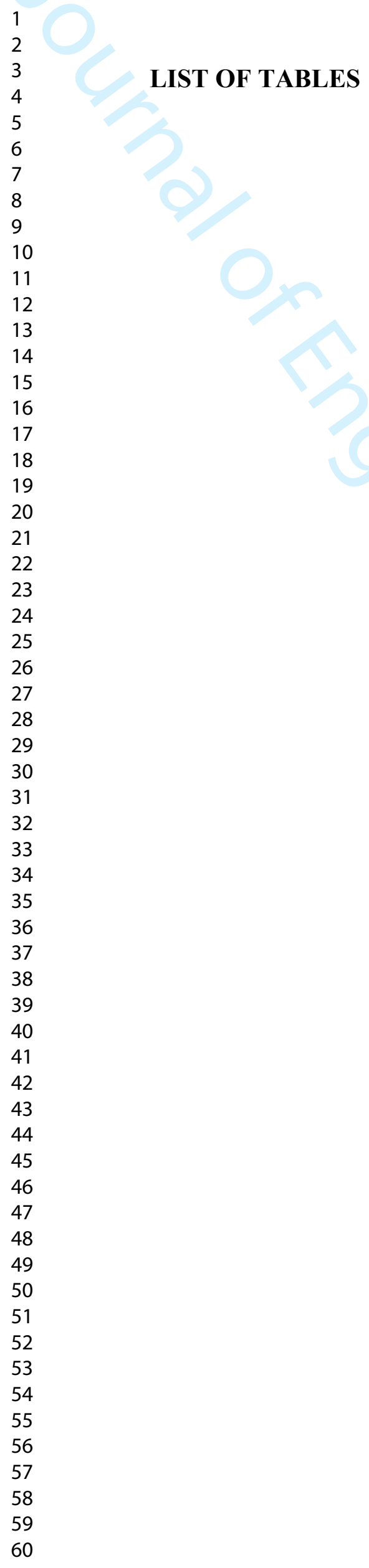

31 
Table 1: Course studied at level 4/5

\begin{tabular}{|l|l|l|l|l|}
\hline \multicolumn{4}{|c|}{ BIM Groups (2017 Specification) } & \multicolumn{2}{l|}{$\begin{array}{l}\text { Non BIM Groups (2010 } \\
\text { Specification) }\end{array}$} \\
\hline & $\begin{array}{l}\text { Number of } \\
\text { students }\end{array}$ & $\begin{array}{l}\text { Number of } \\
\text { students }\end{array}$ & \% \\
\hline Course studying & 26 & $32 \%$ & 12 & $46 \%$ \\
\hline HNC construction & 10 & $12 \%$ & 14 & $54 \%$ \\
\hline HNC Civil Engineering & & & $0 \%$ \\
\hline $\begin{array}{l}\text { HNC Building Services } \\
\text { engineering }\end{array}$ & 34 & $41 \%$ & 0 & $0 \%$ \\
\hline HNC Quantity surveying & 12 & $15 \%$ & 0 & $100 \%$ \\
\hline Total & 82 & $100 \%$ & 26 & \\
\hline
\end{tabular}

Table 2: Mode of study

\begin{tabular}{|l|l|l|l|l|}
\hline & BIM Groups & Non BIM Groups \\
\hline Mode of study & $\begin{array}{l}\text { Number } \\
\text { students }\end{array}$ & of & $\begin{array}{l}\text { Number } \\
\text { students }\end{array}$ & of \\
Percentage
\end{tabular}

Table 3: P1articipants' roles within industry

\begin{tabular}{|l|l|l|l|l|}
\hline & \multicolumn{3}{l|}{ BIM Group } & \multicolumn{2}{l|}{ Non BIM Group } \\
\hline Participants role & $\begin{array}{l}\text { Number of } \\
\text { students }\end{array}$ & $\begin{array}{l}\text { Percentag } \\
\text { e }\end{array}$ & $\begin{array}{l}\text { Number } \\
\text { students }\end{array}$ & $\begin{array}{l}\text { Percentag } \\
\text { e }\end{array}$ \\
\hline Civil engineer & 12 & $14.63 \%$ & 9 & $34.62 \%$ \\
\hline QS & 16 & $19.51 \%$ & 7 & $26.92 \%$ \\
\hline M\&E engineer & 13 & $15.85 \%$ & 0 & $0.00 \%$ \\
\hline Estimator & 3 & $3.66 \%$ & 3 & $11.54 \%$ \\
\hline Site manager & 1 & $1.22 \%$ & 3 & $11.54 \%$ \\
\hline Buyer & 1 & $1.22 \%$ & 0 & $0.00 \%$ \\
\hline Project manager & 4 & $4.88 \%$ & 1 & $3.85 \%$ \\
\hline Designer & 18 & $21.95 \%$ & 3 & $11.54 \%$ \\
\hline Other & 13 & $15.85 \%$ & 0 & $0.00 \%$ \\
\hline Not working in industry & 1 & $1.22 \%$ & 0 & $0.00 \%$ \\
\hline Total & 82 & $100 \%$ & 26 & $100.00 \%$ \\
\hline
\end{tabular}

Table 4: Awareness of BIM

\begin{tabular}{|l|l|l|l|l|}
\hline & \multicolumn{2}{|l|}{ BIM Group } & Non BIM Group \\
\hline & $\begin{array}{l}\text { Number } \\
\text { students }\end{array}$ & of & $\begin{array}{l}\text { Number of } \\
\text { students }\end{array}$ & $\%$ \\
\hline Yes & 100 & $100 \%$ & 22 & $85 \%$ \\
\hline No & 0 & $0 \%$ & 4 & $15 \%$ \\
\hline Total & 82 & $100 \%$ & 26 & $100 \%$ \\
\hline
\end{tabular}


Table 5: Adoption of BIM level 2

\begin{tabular}{|l|l|l|l|l|}
\hline & \multicolumn{2}{|l|}{ BIM Group } & Non BIM Group \\
\hline & $\begin{array}{l}\text { Number of } \\
\text { students }\end{array}$ & $\begin{array}{l}\text { Number } \\
\text { of } \\
\text { students }\end{array}$ & \% \\
\hline Every project is BIM level 2 & 7 & $9 \%$ & 1 & $4 \%$ \\
\hline $\begin{array}{l}\text { More than 50\% of projects are BIM } \\
\text { level 2 }\end{array}$ & 20 & $24 \%$ & 7 & $27 \%$ \\
\hline $\begin{array}{l}\text { Less than 50\% of projects BIM } \\
\text { level 2 }\end{array}$ & 21 & $26 \%$ & 10 & $38 \%$ \\
\hline No projects are BIM level 2 & 20 & $24 \%$ & 4 & $15 \%$ \\
\hline don't know & 14 & $17 \%$ & 4 & $15 \%$ \\
\hline Total & 82 & $100 \%$ & 26 & $100 \%$ \\
\hline
\end{tabular}

Table 6: Awareness of 4D modelling

\begin{tabular}{|l|l|l|l|l|}
\hline & BIM Group & Non BIM Group \\
\hline Awareness of 4D modelling & $\begin{array}{l}\text { Number } \\
\text { students }\end{array}$ & of & $\begin{array}{l}\text { Number of } \\
\text { students }\end{array}$ & $\%$ \\
\hline Yes & 71 & $87 \%$ & 10 & $38 \%$ \\
\hline No & 11 & $13 \%$ & 16 & $62 \%$ \\
\hline Total & 82 & $100 \%$ & 26 & $100 \%$ \\
\hline
\end{tabular}

Table 7: Company use of 4D modelling

\begin{tabular}{|l|l|l|l|l|}
\hline & \multicolumn{2}{|l|}{ BIM Group } & Non BIM Group \\
\hline & $\begin{array}{l}\text { Number } \\
\text { students }\end{array}$ & of & $\begin{array}{l}\text { Number } \\
\text { of } \\
\text { Students }\end{array}$ & \% \\
\hline Yes & 28 & $34 \%$ & 4 & $15 \%$ \\
\hline No & 51 & $62 \%$ & 20 & $77 \%$ \\
\hline Do not know & 3 & $4 \%$ & 2 & $8 \%$ \\
\hline Total & 82 & $100 \%$ & 26 & $100 \%$ \\
\hline
\end{tabular}

Table 8: Benefits of 4D modelling

\begin{tabular}{|l|l|l|l|l|l|l|}
\hline BIM Group & Mean & SDev & Ranking & Mean & SDev & Ranking \\
\hline Benefit & 3.59 & 1.02 & 6 & 3.69 & 0.73 & 6 \\
\hline Cost Management & 4.00 & 0.85 & 2 & 4.23 & 0.81 & 2 \\
\hline Accuracy of schedule & 3.94 & 0.93 & 3 & 3.96 & 0.87 & 3 \\
\hline Schedule monitoring & 3.52 & 1.04 & 7 & 3.38 & 0.80 & 8 \\
\hline Agreeing workflow & 3.21 & 1.05 & 8 & 3.62 & 0.94 & 7 \\
\hline H\&S Management & 3.80 & 1.00 & 4 & 3.73 & 0.87 & 5 \\
\hline Logistics management & 3.15 & 0.98 & 9 & 2.92 & 1.05 & 9 \\
\hline Reduce waste & 3.68 & 0.99 & 5 & 3.88 & 0.81 & 4 \\
\hline Communication & 4.67 & 0.75 & 1 & 4.58 & 0.64 & 1 \\
\hline Visual & & & & & \\
\hline
\end{tabular}


Table 9: Pre and post test results (perception of 4D as a tool for health and safety management)

\begin{tabular}{|l|l|l|}
\hline & BIM group & Non BIM group \\
\hline Initial perception & 3.54 & 3.81 \\
\hline Perception after demonstration & 3.21 & 3.62 \\
\hline Difference & $\mathbf{- 0 . 3 3}$ & $\mathbf{- 0 . 1 9}$ \\
\hline
\end{tabular}

Table 10: Impact on planning for health \& safety

\begin{tabular}{|l|l|l|l|l|}
\hline & \multicolumn{2}{|l|}{ BIM Group } & \multicolumn{2}{l|}{ Non BIM Group } \\
\hline Variable & Mean & Ranking & Mean & Ranking \\
\hline Planning site logistics & 3.89 & 2 & 4.12 & 1 \\
\hline Planning Work at Height & 3.52 & 3 & 3.46 & 3 \\
\hline Planning plant locations and movement & 4.00 & 1 & 3.77 & 2 \\
\hline Planning pedestrian segregation & 3.49 & 4 & 3.04 & 4 \\
\hline Planning for Manual Handle tasks & 2.62 & 6 & 2.42 & 6 \\
\hline Planning for tasks in Confined Spaces & 2.63 & 5 & 2.88 & 5 \\
\hline
\end{tabular}


Page 35 of 40

Journal of Engineering, Design and Technology

1

2

3

4

5

6

7

8

9

10

11

12

13

14

15

16

17

18

19

20

21

22

23

24

25

26

27

28

29

30

31

32

33

34

35

36

37

38

39

40

41

42

43

44

45

46

47

48

49

50

51

52

53

54

55

56

57

58

59

60

LIST OF TABLES 
Table 1: Course studied at level 4/5

\begin{tabular}{|l|c|c|c|c|}
\hline \multicolumn{2}{|c|}{ BIM Groups (2017 Specification) } & \multicolumn{2}{c|}{ Specification) } \\
\multicolumn{1}{|c|}{ Course studying } & Number of & & Number of & \\
\hline HNC construction & students & $\%$ & students & $\%$ \\
\hline HNC Civil Engineering & 26 & $32 \%$ & 12 & $46 \%$ \\
\hline HNC Building Services & 10 & $12 \%$ & 14 & $54 \%$ \\
\hline engineering & 34 & $41 \%$ & 0 & $0 \%$ \\
\hline HNC Quantity surveying & 12 & $15 \%$ & 0 & $0 \%$ \\
\hline Total & 82 & $100 \%$ & 26 & $100 \%$ \\
\hline
\end{tabular}

Table 2: Mode of study

\begin{tabular}{|l|r|r|r|r|}
\hline \multirow{2}{*}{ Mode of study } & \multicolumn{2}{|c|}{ BIM Groups } & \multicolumn{2}{c|}{ Non BIM Groups } \\
\hline Number of & & \multicolumn{2}{c|}{ Number of } & \\
\hline Full time & students & Percentage & students & Percentage \\
\hline Part time & 0 & $0 \%$ & 0 & $0 \%$ \\
\hline Total & 82 & $100 \%$ & 26 & $100 \%$ \\
\hline
\end{tabular}

Table 3: P1articipants' roles within industry

\begin{tabular}{|l|c|c|c|c|}
\hline & \multicolumn{2}{|c|}{ BIM Group } & \multicolumn{2}{c|}{ Non BIM Group } \\
\hline & Number of & Percentag & Number of & Percentag \\
Participants role & students & e & students & e \\
\hline
\end{tabular}




\begin{tabular}{|l|c|c|c|c|}
\hline Civil engineer & 12 & $14.63 \%$ & 9 & $34.62 \%$ \\
\hline QS & 16 & $19.51 \%$ & 7 & $26.92 \%$ \\
\hline M\&E engineer & 13 & $15.85 \%$ & 0 & $0.00 \%$ \\
\hline Estimator & 3 & $3.66 \%$ & 3 & $11.54 \%$ \\
\hline Site manager & 1 & $1.22 \%$ & 3 & $11.54 \%$ \\
\hline Buyer & 1 & $1.22 \%$ & 0 & $0.00 \%$ \\
\hline Project manager & 4 & $4.88 \%$ & 1 & $3.85 \%$ \\
\hline Designer & 18 & $21.95 \%$ & 3 & $0.00 \%$ \\
\hline Other & 13 & $15.85 \%$ & 0 & $0.00 \%$ \\
\hline Not working in industry & 1 & $1.22 \%$ & 0 & $100.00 \%$ \\
\hline Total & 82 & $100 \%$ & 26 & \\
\hline
\end{tabular}

Table 4: Awareness of BIM

\begin{tabular}{|l|c|c|c|c|}
\hline & \multicolumn{2}{|c|}{ BIM Group } & \multicolumn{2}{c|}{ Non BIM Group } \\
\hline \multirow{2}{*}{ Awareness of BIM } & Number of & & Number of & \\
\hline Yes & students & $\%$ & students & $\%$ \\
\hline No & 100 & $100 \%$ & 22 & $85 \%$ \\
\hline Total & 0 & $0 \%$ & 4 & $15 \%$ \\
\hline
\end{tabular}


Table 5: Adoption of BIM level 2

\begin{tabular}{|c|c|c|c|c|}
\hline 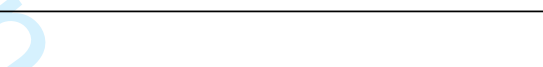 & \multicolumn{2}{|c|}{ BIM Group } & \multicolumn{2}{|c|}{ Non BIM Group } \\
\hline BIM adoption & $\begin{array}{l}\text { Number of } \\
\text { students }\end{array}$ & $\%$ & $\begin{array}{c}\text { Number } \\
\text { of } \\
\text { students }\end{array}$ & $\%$ \\
\hline Every project is BIM level 2 & 7 & $9 \%$ & 1 & $4 \%$ \\
\hline $\begin{array}{l}\text { More than } \mathbf{5 0 \%} \text { of projects are } \\
\text { BIM level } 2\end{array}$ & 20 & $24 \%$ & 7 & $27 \%$ \\
\hline $\begin{array}{l}\text { Less than } \mathbf{5 0 \%} \text { of projects BIM } \\
\text { level } 2\end{array}$ & 21 & $26 \%$ & 10 & $38 \%$ \\
\hline No projects are BIM level 2 & 20 & $24 \%$ & 4 & $15 \%$ \\
\hline don't know & 14 & $17 \%$ & 4 & $15 \%$ \\
\hline Total & 82 & $100 \%$ & 26 & $100 \%$ \\
\hline
\end{tabular}

Table 6: Awareness of 4D modelling

\begin{tabular}{|l|c|c|c|c|}
\hline & \multicolumn{2}{|c|}{ BIM Group } & \multicolumn{2}{c|}{ Non BIM Group } \\
\hline \multirow{2}{*}{ Awareness of 4D modelling } & Number of & & Number of & \\
\hline Yes & students & $\%$ & students & $\%$ \\
\hline No & 71 & $87 \%$ & 10 & $38 \%$ \\
\hline Total & 11 & $13 \%$ & 16 & $62 \%$ \\
\hline
\end{tabular}

Table 7: Company use of 4D modelling

\begin{tabular}{|l|l|l|}
\hline & BIM Group & Non BIM Group \\
\hline
\end{tabular}




\begin{tabular}{|l|c|c|c|c|}
\hline & Number of & & $\begin{array}{c}\text { Number } \\
\text { of }\end{array}$ & \\
Company use of 4D modelling & students & $\%$ & students & $\%$ \\
\hline Yes & 28 & $34 \%$ & 4 & $15 \%$ \\
\hline No & 51 & $62 \%$ & 20 & $77 \%$ \\
\hline Do not know & 3 & $4 \%$ & 2 & $8 \%$ \\
\hline Total & 82 & $100 \%$ & 26 & $100 \%$ \\
\hline
\end{tabular}

Table 8: Benefits of 4D modelling

\begin{tabular}{|l|c|c|c|c|c|c|}
\hline \multicolumn{2}{|c|}{ BIM Group } & \multicolumn{3}{c|}{ Non BIM Group } \\
\hline Benefit & Mean & SDev & Ranking & Mean & SDev & Ranking \\
\hline Cost Management & 3.59 & 1.02 & 6 & 3.69 & 0.73 & 6 \\
\hline Accuracy of schedule & 4.00 & 0.85 & 2 & 4.23 & 0.81 & 2 \\
\hline Schedule monitoring & 3.94 & 0.93 & 3 & 3.96 & 0.87 & 3 \\
\hline Agreeing workflow & 3.52 & 1.04 & 7 & 3.38 & 0.80 & 8 \\
\hline H\&S Management & 3.21 & 1.05 & 8 & 3.62 & 0.94 & 7 \\
\hline Logistics management & 3.80 & 1.00 & 4 & 3.73 & 0.87 & 5 \\
\hline Reduce waste & 3.15 & 0.98 & 9 & 2.92 & 1.05 & 9 \\
\hline Communication & 3.68 & 0.99 & 5 & 3.88 & 0.81 & 4 \\
\hline Visual & 4.67 & 0.75 & 1 & 4.58 & 0.64 & 1 \\
\hline
\end{tabular}

Table 9: Pre and post test results (perception of 4D as a tool for health and safety management)

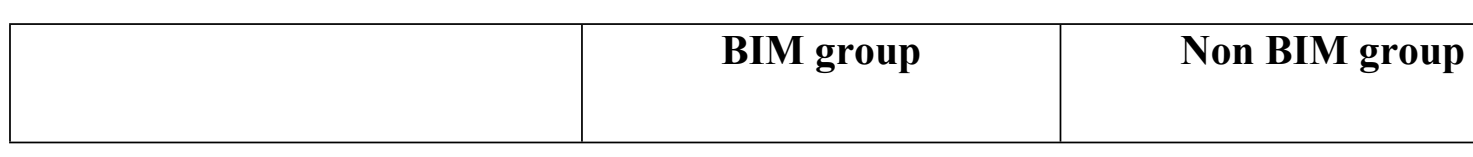




\begin{tabular}{|l|c|c|}
\hline Initial perception & 3.54 & 3.81 \\
\hline Perception after demonstration & 3.21 & 3.62 \\
\hline Difference & $\mathbf{- 0 . 3 3}$ & $\mathbf{- 0 . 1 9}$ \\
\hline
\end{tabular}

Table 10: Impact on planning for health \& safety

\begin{tabular}{|l|c|c|c|c|}
\hline & \multicolumn{2}{|c|}{ BIM Group } & \multicolumn{2}{c|}{ Non BIM Group } \\
\hline Variable & Mean & Ranking & Mean & Ranking \\
\hline Planning site logistics & 3.89 & 2 & 4.12 & 1 \\
\hline Planning Work at Height & 3.52 & 3 & 3.46 & 3 \\
\hline Planning plant locations and movement & 4.00 & 1 & 3.77 & 2 \\
\hline Planning pedestrian segregation & 3.49 & 4 & 3.04 & 4 \\
\hline Planning for Manual Handle tasks & 2.62 & 6 & 2.42 & 6 \\
\hline Planning for tasks in Confined Spaces & 2.63 & 5 & 2.88 & 5 \\
\hline
\end{tabular}

